\title{
Impact of Bimanual Vaginal Examination on Pap Smear Test Results
}

\author{
Esengül TÜRKYILMAZ', Melahat YILDIRIM², Raziye DESDİCİĞLU², Huban Sibel ORHUN YAVUZ \\ Ayşe Filiz YAVUZ AVŞAR ${ }^{2}$
}

Ankara, Turkey

\begin{abstract}
OBJECTIVE: The aim of the study is to evaluate the possible effects of the various conditions especially bimanual examination on the adequacy of pap smear test.

STUDY DESIGN: Presented here is a prospective controlled clinical trial carried out at Ankara Atatürk Training and Research Hospital between November 2013 and March 2014. Total of 1771 patients seen at the gynecology outpatient clinic were included in the study. The technique described by the American Society of Cytopathology Criteria 2000 for the preparation of the specimen was followed. Updated Bethesda system 2014 was used for reporting the results.
\end{abstract}

RESULTS: Number of subjects in smear before examination group was 1194 and in the smear after examination group was 577 . Two percent ( $n=36$ subjects) of the cervicovaginal report was inadequate. When other clinical conditions were not taken into consideration, the likelihood ratio for inadequate smear in the smear after examination group was 2.64 compared to smear before examination group $(p=0,004)$.

CONCLUSIONS: In some conditions cervicovaginal smear sampling may be carried out after bimanual vaginal examination instead of missing the chance to screen the women. However, the patients have to be informed that cervicovaginal smear result might be inadequate so that a repeat test has to be carried out.

Keywords: Pap smear, Cytological technique, Pelvic examination

Gynecol Obstet Reprod Med 2017;23(1):26-31

\section{Introduction}

Papanicolaou test is a widely used effective screening test for cervical pathologies. During the last 50 years, the mortality rate from cervical carcinoma has decreased $80 \%$ due to Papanicolaou screening test $(1,2)$. Therefore, it is utmost important to routinely screen sexually active women at

${ }^{I}$ Department of Obstetrics and Gynecology, Atatürk Training and Research Hospital, Ankara

2 Department of Obstetrics and Gynecology, Ylldirlm Beyazıt University, Ankara

${ }^{3}$ Department of Pathology, Ataturk Training and Research Hospital, Ankara

Address of Correspondence: Esengül Türkyllmaz

Department of Obstetrics and

Gynecology, Atatürk Training and

Research Hospital Ankara, Turkey turkyilmaz06@yahoo.com

Submitted for Publication: $\quad 30.11 .2016$

Accepted for Publication: $\quad 08.12 .2016$

\begin{tabular}{|c|c|}
\hline & Access this article online \\
\hline $\begin{array}{c}\text { Quick Response Code: } \\
\text { ? }\end{array}$ & Website: www.gorm.com.tr \\
\cline { 2 - 2 } & DOI:10.201613/GORM.2016.646 \\
\hline
\end{tabular}

How to cite this article: Türkyllmaz E. Ylldırlm M. Desdicioğlu R. Orhun Yavuz HS. Yavuz Avșar AF. Impact of Bimanual Vaginal Examination on Pap Smear Test Results. Gynecol Obstet Reprod Med 2017;23(1):26-31 regularly defined intervals and do not miss any opportunity for screening.

Even though the test is widely used, inadequate sampling is still an important problem (3). Physicians should be aware of the reasons for inadequate sampling. The drawbacks of such reports are the need for repeat testing that will take time, cost extra labor and money. Meanwhile, patients might be lost from follow-up such that cervical pathologies might be missed. The reasons for inadequate smear are inappropriate sampling (preparation), inadequate cell number due to blood cells or mucous overlying the cells and interpretation mistakes (4). Inadequate cell number is the most common and not to overcome reason as now (5). Even though there are no studies about the timing of doing the Pap Smear test during a gynecological examination, the widespread approach in practice is to take the sample before doing the bimanual examination. However, there are various situations that are actually not so infrequent when the chance for carrying out the procedure is missed such that the physician might forget to ask before the examination when the patient had her last smear test, the information the patient gives turns out to be wrong or since the cervix might not be visualized with a speculum, bimanual examination has to be carried out first.

The primary aim of the study is to evaluate the possible effects of the various conditions especially bimanual examina- 
tion on the adequacy of pap smear test. The secondary aim is to evaluate for possible factors that would affect presence of endocervical/transformation zone component.

\section{Material and Method}

Presented here is a prospective controlled clinical trial carried out at Ankara Ataturk Training and Research Hospital between November 2014 and March 2015. Total of 1771 patients seen at the gynecology outpatient clinic were included in the study. Ethics committee approval was taken before the study. And written informed consents were taken all of the participants.

Exclusion criteria were refusing to have a bimanual examination, history of hysterectomy, radiation therapy or chemotherapy, conditions previously shown to affect the adequacy of the smear test like sexual intercourse or vaginal douching during the last 24 hours and use of vaginal medication during the last seven days.

Information about age of the patient, obstetrical history, presence of vaginal delivery, history of any cervical operation (loop electrosurgical excision procedure, conization, cauterization, cryotherapy, etc.), presence of intrauterine device (IUD), menopausal status and date of cycle at the time of examination were all recorded. Patients were allocated in two groups: smear before and smear after the bimanual examination. All the examinations were carried out by the same physician. The sample for the smear test was taken using a plastic speculum without application of any gel by Cervix Brush /smear brush SMF 41. The technique described by the American Society of Cytopathology Criteria 2000 for the preparation of the specimen was followed (6). All the samples were taken to the pathology laboratory in half an hour and evaluated by the same pathologist who was blind to the group number. Updated Bethesda system 2014 was used for reporting the results (7). For conventional smear, number of squamous cells good preserved and visible to the naked eye less than 10000, and blood, inflammation or other processes covering more than $75 \%$ of the slide area is considered as inadequate sample for evaluation (8).

Statistical analysis was carried out using IBM SPSS Statistics 21.0 (IBM Corp. Released 2012. IBM SPSS Statistics for Windows, Version 21.0. Armonk, NY: IBM Corp.) and MS-Excel 2007 program. Comparison of adequacy for different variables was performed with chi-squared test, a univariate analysis was performed for possible factors that would affect inadequacy of cytological examination and presence of endocervical/transformation zone component. Multivariate analyses were performed for possible factors that would affect presence of endocervical/transformation as open zone component. A power was performed by using computer based calculator kit based on the rates of smear adequacy before and after examination. Power of this study was $93.5 \%$ with an Alpha of 5\% corresponds to a 95\% Confidence Interval.

\section{Results}

Total of 1771 patients were recruited into study. Number of subjects in smear before examination group was 1194 and in smear after examination group was 577. In smear before examination group the median (minimum; maximum) age, gravidity, parity, number of cycle day and menopause period were respectively 41(18;79) years, $2(0 ; 13), 2(0 ; 13), 15$ (1$240)$ and 6 (1-30). In smear after examination group the median (minimum-maximum) value of these variables were respectively 43 (17;84), $3(0 ; 15), 2(0 ; 12), 15(3 ; 210), 7$ (0;41). There are significant differences between age and gravida number ( $P$ values of these variables are respectively $p=0.002$; $<0.001)$. There are no significant differences between parity, cycle day, menopause duration ( $\mathrm{p}$ values are respectively $(p=0.92 ; 0.52 ; 0.395) .226(21.4 \%)$ of the patients whose smears were taken before examination were nulliparous and $99(20.3 \%)$ of the patients whose smears were taken after examination were nulliparous. $168(14.1 \%)$ of the patients whose smears were taken before examination and $63(10.9 \%)$ of the patients whose smears were taken after examination have IUD. 237 (19.8\%) of the patients whose smears were taken before examination and $193(33.4 \%)$ of the patients whose smears were taken after examination are postmenopausal womens.13 (1.1\%) of the patients whose smears were taken before examination and $10(1.7 \%)$ of the patients whose smears were taken after examination have cervical operation history. There was significant difference between menopause situation and smear sampling time $(\mathrm{p}<0.001)$ but statistically significant difference wasn't detected between smear sampling time and cervix situation, presence of IUD, cervical operation history.

Endocervical/transformation zone wasn't detected 318 (26.6\%) of the patients whose smears were taken before examination and $135(23.4 \%)$ of the patients whose smears were taken after examination. Distribution of the smear specimens' pathological evaluation results according to the smear sampling time was given at table 1 . There were no significant differences between smears taken before examination and taken after examination in terms of presence of endocervi$\mathrm{cal} /$ transformation zone, intraepithelial lesion/malignancy, inflammatory cellular changes and specific microorganism ( $\mathrm{P}$ values are respectively; $\mathrm{p}=0.143 ; 0.926 ; 0.053 ; 0.966)$. Atrophic vaginitis ratio of the smears taken after examination is $13 \%$ and there were significant differences between atrophic vaginitis ratio of the smears taken before examination $(8 \%)$ and taken after examination $(p=0.002)$. Distribution of categorical variables according to adequacy of the smear was given in table 2 .

Sixteen $(2 \%)$ of the patients whose smears were taken before examination and $20(4 \%)$ of the patients whose smears 
were taken after examination were evaluated as inadequate. Cytological result was adequate in $98.1 \%$ of patients who had vaginal deliveries and in $99.1 \%$ of those who did not have history of vaginal delivery. In $97.4 \%$ of subjects with IUD and in $98.1 \%$ of subjects without IUD, cytology report was adequate. Among menopausal subjects, the incidence of cytolog- ical adequacy was $98.4 \%$ whereas non-menopausal subjects had $97.8 \%$ adequate cytology. Patients with and without cervical operation history had respectively $95.7 \%$ and $98.0 \%$ adequate cytology. Comparing of the variables defined at the patients whose smears were inadequate with the smear sampling time was given in table 3 .

Table 1: Distribution of the smear specimens' pathological evaluation results according to the smear sampling time

\begin{tabular}{|c|c|c|c|c|c|}
\hline \multirow[b]{2}{*}{$\begin{array}{l}\text { Presence of } \\
\text { endocervical/ } \\
\text { transformation zone } \\
\text { Absent } \\
\text { Present }\end{array}$} & $\begin{array}{c}\text { Before examination } \\
\mathrm{n}(\%)\end{array}$ & $\begin{array}{c}\text { After examination } \\
\mathrm{n}(\%)\end{array}$ & & $\begin{array}{c}\text { Before examination } \\
\mathrm{n}(\%)\end{array}$ & $\begin{array}{c}\text { After examination } \\
\mathrm{n}(\%)\end{array}$ \\
\hline & $\begin{array}{l}318(26) \\
876(74)\end{array}$ & $\begin{array}{l}135(23) \\
442(77)\end{array}$ & $\begin{array}{l}\text { Inflammatory cellular } \\
\text { changes } \\
\text { Absent } \\
\text { Present }\end{array}$ & $\begin{array}{l}515(43) \\
679(57)\end{array}$ & $\begin{array}{l}277(48) \\
300(52)\end{array}$ \\
\hline $\begin{array}{l}\text { Presence of } \\
\text { intraepithelial } \\
\text { lesion } \\
\text { Absent } \\
\text { Present }\end{array}$ & $\begin{array}{l}1173(98) \\
22(2)\end{array}$ & $\begin{array}{l}566(98) \\
11(2)\end{array}$ & $\begin{array}{l}\text { Presence of specific } \\
\text { microorganism } \\
\text { Absent } \\
\text { Present }\end{array}$ & $\begin{array}{l}1116(93.5) \\
78(6.5)\end{array}$ & $\begin{array}{l}539(93.4) \\
38(6.6)\end{array}$ \\
\hline \multirow[t]{2}{*}{$\begin{array}{l}\text { Variety of } \\
\text { intraepithelial } \\
\text { lesion } \\
\text { ASCUS } \\
\text { L-SIL } \\
\text { H-SIL } \\
\text { AGUS }\end{array}$} & \multirow[t]{2}{*}{$\begin{array}{l}13(1) \\
6(0.5) \\
1(0.5) \\
1(0.5)\end{array}$} & \multirow[t]{2}{*}{$\begin{array}{ll}6 & (1) \\
1 & (0.1) \\
4 & (0.6) \\
0 & (0.0)\end{array}$} & $\begin{array}{l}\text { Variety of specific } \\
\text { microorganism } \\
\text { Bacterial vaginosis } \\
\text { Candida } \\
\text { Actinomyces }\end{array}$ & $\begin{array}{l}51(4) \\
24(2) \\
2(0.1)\end{array}$ & \begin{tabular}{|l}
$32(5)$ \\
$6(1)$ \\
$1(0.1)$
\end{tabular} \\
\hline & & & $\begin{array}{l}\text { Atrophic vaginitis } \\
\text { Absent } \\
\text { Present }\end{array}$ & $\begin{array}{l}1089(92) \\
99(8)\end{array}$ & $\begin{array}{l}488(87) \\
74(13)\end{array}$ \\
\hline
\end{tabular}

Table 2: Distribution of categorical variables according to adequacy of the smear

\begin{tabular}{|l|l|l|}
\hline Variables (n=1771) & \multicolumn{2}{|c|}{$\begin{array}{c}\text { Adequacy of smear specimen } \\
\text { Inadequate }\end{array}$} \\
\hline $\begin{array}{l}\text { Smear sampling time } \\
\text { Before examination } \\
\text { After examination }\end{array}$ & $\begin{array}{l}|c| \\
1178(98) \\
557(96)\end{array}$ & $16(2)$ \\
\hline $\begin{array}{l}\text { History of vaginal birth } \\
\text { Absent }\end{array}$ & $322(4)$ \\
Present & $1195(98.1)$ & $3(0.9)$ \\
\hline $\begin{array}{l}\text { Presence of intrauterine device } \\
\text { Absent }\end{array}$ & $1510(98.1)$ & $23(1.9)$ \\
Present & $225(97.4)$ & $30(1.9)$ \\
\hline $\begin{array}{l}\text { Menopause situation } \\
\text { Absent }\end{array}$ & $1312(97.8)$ & $6(2.6)$ \\
Present & $423(98.4)$ & $29(2.2)$ \\
\hline History of cervical operation & $1713(98.0)$ & $7(1.6)$ \\
Absent & $22(95.7)$ & $35(2.0)$ \\
Present & & $1(4.3)$ \\
\hline
\end{tabular}


Table 3: Comparing of the variables defined at the patients whose smears were inadequate with the smear sampling time

\begin{tabular}{|l|c|c|}
\hline \multirow{2}{*}{ Variables } & \multicolumn{2}{|c|}{ Smear sampling time } \\
\cline { 2 - 4 } & Before examination $\mathbf{n ~ ( \% )}$ & After examination $\mathbf{n}(\%)$ \\
\hline Cervix situation & & $2(66.7)$ \\
\hline Nulliparous & $1(33.3)$ & $11(47.8)$ \\
\hline Multiparous & $12(52.2)$ & $19(63.3)$ \\
\hline Presence of IUD device & $11(36.7)$ & $1(16.7)$ \\
\hline Absent & $5(83.3)$ & \\
\hline Present & $14(48.3)$ & $15(51.7)$ \\
\hline Menopause situation & $2(28.6)$ & $5(71.4)$ \\
\hline Absent & & 1.000 \\
\hline Present & $16(45.7)$ & $19(54.3)$ \\
\hline History of cervical operation & $0(0.0)$ & $1(100.0)$ \\
\hline Absent & & \\
\hline Present & & \\
\hline
\end{tabular}

When other clinical conditions were not taken into consideration, the likelihood ratio for inadequate smear in the smear after examination group was 2.64 compared to smear before examination group ( $p=0.004)$. Age, gravidity, parity, presence of IUD, menopausal status and history of cervical operation had no statistically significant effect on adequacy of smear.

In univariate analyses, timing of smear sampling, situation of cervix (nulliparous/multiparous), presence of IUD and cycle day had statistically significant effect on presence of endocervical/transformation zone. In multivariate analyses just presence of IUD had statistically significant effect on presence of endocervical/transformation zone $(\mathrm{p}=0,047 ; \mathrm{OR}=1,5)$.

\section{Discussion}

This study showed that the adequacy of smear test was significantly lower when specimen was taken after compared to before bimanual examination. Even though non powdered gloves were used and no lubricant was applied, still the result was the same. This might be due to deformation of cells and minimal bleeding after bimanual examination.

Gilson et al. studied the effect of gel application during pap smear test. They found that it had no negative effect on the cytological evaluation of cervicovaginal smear, and that stated that it might be used for the comfort of the patient if she chooses (9). Moreover, it was proposed that bimanual examination could be carried out by using gel if the cervix was not visible with a speculum (9). However, this suggestion is not evidence based. In this present study, even though non powdered gloves were used and no lubricant gel was applied, adequacy of smear test was significantly lower when specimen was taken after compared to before bimanual examination. This finding is not in accordance with the suggestion of Gilson's study.
There are various reports in the literature about clinical parameters known to affect cervicovaginal smear adequacy (5). Kosus et al. found lower incidence of inadequate smear report in menopausal women, but was not statistically significant (10). In accordance with this, this present study did not found any difference between groups with respect to effect of menopausal status on adequacy of smear $(p=0.496)$. Cause of the significant difference between atrophic vaginitis ratio of the smears taken before examination and after examination is menopause situation of the patients whose smears were taken after examination is significantly higher than of the patients whose smears were taken before examination.

NTCC (New Technologies in Cervical Cancer Screening) is a randomized clinical study carried out in Italy among women of 25-60 years of age comparing HPV DNA test and new techniques of Liquid base cytology (LBC) with Conventional Papanicolaou test (CP) NETHCON (Netherlands Thin Prep versus Conventional Cytology) is another randomized clinical trial comparing LBC and CP among women aged 30 to 60 years with histologically proven cervical intraepithelial lesions. The incidence of inadequate smear results decreased minimally in CP group in NTCC whereas increased in NETHCON as age increased. Other studies also found a relationship between age and inadequacy of smears $(5,11)$. However, our study contradicted this by finding no increase in incidence of adequate reports as age increased $(p=0.852)$.

Some reports showed inadequacy when smear was taken during the first days of cycle (11). In contrast, no significant relationship was found between adequacy and timing of sampling with regard to days of menstrual cycle $(p=0.268)$ in this present study. The only clinical condition that influenced the incidence of adequate smear result was the condition of being taken before or after the bimanual examination. The incidence 
of inadequate smear was lower than in other reports $(5,12,13)$. This observed lower inadequacy ratio is might be due to good application of the technique, having the same physician, and exclusion of clinical conditions that adversely affect the performance of the test.

Absence of endocervical component was $24.3 \%(n=421)$ in this study. Presence of IUD ability to increase the rate of presence of the endocervical/transformation zone because of kept of the cervical os $(p=0,047 ; O R=1,5)$. Some reports showed increased incidence of abnormal epithelial changes when endocervical cells were not present in the smear specimen $(14,15)$ whereas others contradicted this finding $(16,17,18)$. Absence of endocervical component should not be the only criteria to repeat the test earlier than routine $(19,20)$. Previous smear results and clinical findings should also be taken into consideration.

Management of inadequate smear results is to repeat the test in two to four months (21). Many reports showed an association with high incidence of invasive carcinoma and intraepithelial lesion with inadequate smear (22-24). In the study presented here, for inadequate results in postmenopausal women, the test was repeated after local estrogen therapy, and in patients with cervicovaginal infection, it was repeated after appropriate infection therapy. However, many of these patients were lost to follow up and only eight out of 36 patients came back for repeat testing. In those, the repeated smear test results were adequate. This showed how important it was to treat the conditions like atrophy or infection that caused inadequate results before performing the smear test.

This study might be designed as taking the smear before and after the bimanual examination from the same patient. However, knowing that since smear test relies on the amount of shedding of cervicovaginal cells, it was thought that a second test in the same time from the same patient might lead to too few cells to be examined for the second test. Previous reports evaluating the clinical conditions that might lead to inadequate smear results were all retrospective $(5,11)$. In these studies, in addition to univariate analyses multivariate analyses was performed for possible factors that would affect inadequacy of cytological examination. The strength of this study presented here is that it is prospective, the exclusion criteria was well defined to exclude many clinical conditions that might hinder adequacy, the sampling technique is followed meticulously, the same physician took all the samples. As a result, only in $2 \%(n=36)$ patients the results were inadequate. Since this number was too small for multivariate analysis, this is the main limitation of the study.

As much as we know, this is the first prospective study evaluating if pap smear test taken after bimanual vaginal examination is adequate for evaluation. There are some clinical situations such as the physician might forget to ask before the examination when the patient had her last smear test, the in- formation the patient gives turns out to be wrong or since the cervix might not be visualized with a speculum, bimanual examination has to be carried out first when instead of missing the chance to take smear test, it could be taken after the examination. However, the patients have to informed that cervicovaginal smear result might be inadequate so that a repeat test has to be carried out. In addition, in such cases, meticulous attention should be paid to stick to the proper technique and medical equipment.

\section{References}

1. Papanicolaou GN, Traut HF. The diagnostic value of vaginal smears in carcinoma of the uterus. Arch Pathol Lab Med 1997;121(3):211-24.

2. Cervix cancer screening. In: International Agency for Research on Cancer. IARC handbooks of cancer prevention. Lyo: IARC Press; 2005.

3. Spence AR, Goggan P, Franco EL. Process of care failures in invasive cervical cancer; systematic review and metaanalysis. Preventive Medicine 2007;45(2-3):93-106.

4. Abulafia O, Sherer DM. Automated cervical cytology: meta-analyses of the performance of the PAPNET system. Obstet Gynecol Surv 1999;54(4):253-64.

5. Gupta S, Sodhani P, Sardana S, Singh V, Sehgal A. Clinical determinants and smear characteristics of unsatisfactory conventional cervicovaginal smears. Eur J Obstet Gynecol Reprod Biology 2013;168(2):214-7.

6. American Society of Cytopathology Criteria 2000. Available from: www. Cytopathology. Org

7. Nayar, Ritu, Wilbur, David. The Bethesda system for reporting cervical cytology. Definitions, criteria, and explanatory notes 2015. DOI:10.1007/978-3-319-110745 1.

8. Solomon D, Davey D, Kurman R, Moriarty A, O'Connor D, Prey M, et al. The 2001 Bethesda System: Terminology for reporting results of cervical cytology. JAMA 2002; 287(16):2114-9.

9. Gilson M, Desai A, Cardoza-Favarato G, Vroman P, Thornton JA. Does Gel Affect Cytology or Comfort in the screening Papanicolaou Smear? Journal of the American Board of Family Medicine 2006;19(4):340-4.

10. Köşüş A, Köşüş N, Duran M, Haltaş H, Hızlı D, Kafalı H. Effect of liquid-based gel application during speculum examination on satisfactory level of smear examination. Arch Gynecol Obstet 2012;285(6):1599-602.

11. Paulin H, Geldenhys L, Naugler C. Predictors of an unsatisfactory conventional cervical cytology smear. J Obstet Gynaecol Can 2011;33(7):725-8.

12. Lu CH, Chang CC, Chang MC, Chen SJ, Jan YJ, Fu TF, et al. Clinical parameters associated with unsatisfactory specimens of conventional cervical smears. Diagn Cytopathol 2011;39(2):87-91. 
13. Castle PE, Bulten J, Confortini M, Klinkhamer $\mathrm{P}$, Pellegrini A, Siebers AG, et al. Age-specific patterns of unsatisfactory results for conventional Papsmears and liquid-based cytology: data from two randomized clinical trials. BJOG 2010;117:1067-73.

14. Kristensen GB, Skyggebjerg KD, Holund B, Holm K, Hansen MK. Analysis of cervical smears obtained within three years of the diagnosis of invasive cervical cancer. Acta Cytol 1991;35(1):47-50.

15. Vooijs PG, Elias A, Van der Graaf Y, Veling S. Relationship between the diagnosis of epithelial abnormalities and the composition of cervical smears. Acta Cytol 1985;29(3):323-8.

16. Mitchell H, Medley G. Longitudinal study of women with negative cervical smears according to endocervical status: Victorian Cytology Service, Melbourne, Australia. Lancet 1991;337(8736):265-7.

17. Giorgi Rossi P, Baiocchi D, Ciatto S. Endocervical cell Italian working group of cervical cancer screening group. Acta Cytol 2010;54(3):265-71.

18. Tacken MA, Braspenning JC, Mulder J, Hermens RP, Nelen WL, de Bakker DH, et al. Loss to follow-up of cervical smears without endocervical columnar cells is not disturbing. Eur J Gynaecol Oncol 2006;27(1):42-6.

19. Suzanne M. Selvaggi and Barbara J. Guidos. Endocervical Component: Is It a Determinant of Specimen Adequacy. Diagnostic Cytopathology 2002;26(1):53-5.

20. Kurman RJ, Henson DE, Herbst AL, Noller KL, Schiffman MH. Interim guidelines for management of abnormal cervical cytology. JAMA 1994;271(23):1866-9.

21. MembersNccsp. Cervical Cancer Screening: National Comprehensive. Cancer Network, 2009. Accessed 10 August 2009.

22. Hock YL, Ramaiah S, Wall ES, Harris AM, Marston L, Marshall J, et al. Outcome of women with inadequate cervical smears followed up for five years. J Clin Pathol 2003;56(8):592-5.

23. Ransdell JS, Davey DD, Zaleski S. Clinicopathologic correlation of the unsatisfactory Papanicolaou smear. Cancer 1997;81(3):139-43.

24. Karalök A, Koçak Ö, Taşçı T, Yırcı B, Üreyen I, Koç S, et al. Comparison of the Histologic Results of Atypical Glandular Cells-Favor Neoplasia and Atypical Glandular Cells-Not Otherwise Specified. Gynecol Obstet Reprod Med 2016;22(1):27-31 